\title{
CONSTRUCTION AND ENGINEERING LAW IN SOUTH AFRICA: A FUNDAMENTAL GAP IN THE LLB CURRICULUM?
}

\author{
by Quinton Joubert*
}

\section{Introduction}

Since the implementation of a new constitutional dispensation in 1994, South Africa has experienced a tremendous increase in economic development and is now regarded by the world at large as forming part of what is known as the BRICS countries - Brazil; Russia; India; China; and South Africa, all of which are countries experiencing a rapid level of economic growth and development. ${ }^{1}$

Economic development has without a doubt directly resulted in what can be referred to as a 'boom' in the engineering and specifically the building construction industry. Between 2012 and 2013 the overall unadjusted real GDP at market prices increased by $2,0 \%$ year on year. The most outstanding performers by industries in the fourth quarter of 2013 compared to the fourth quarter of 2012 were, among others, the construction industry which increased by 4,5 per cent. ${ }^{2}$

Construction companies throughout South Africa have continuously been active in major projects, the building of new power plants such as Medupi, new road networks, stadiums for the 2010 soccer world cup that was held in South Africa as well as the building of the tunnels and bridges that now host the Gautrain. The extent of communication technology has also seen a growth in recent years and thus calls for further infrastructure by service providers in this area. The environmental conscience of South Africans and many companies in the search for alternative energy sources has also led to a further growth in 'green' technology which is more efficient and productive. ${ }^{3}$ More examples of construction projects include but are not limited to the building of various malls, roads, residential houses, lying out of pipelines, and a number of other engineering feats, etcetera.

Second year LLB student, University of Pretoria.

1 M Fransman (2012) http://www.dfa.gov.za/docs/speeches/2012/frans1121.html (accessed 4 March 2014)

2 http://beta2.statssa.gov.za/publications/P0441/P04414thQuarter2013.pdf

(accessed 4 March 2014).

M Kidd Environmental law (2008) 1. 


\section{Reason for concern}

With such a great level of growth in the construction industry there is now not only a higher demand for civil engineers or quantity surveyors, but also for legal practitioners that are trained in what is referred to as Building and Construction Law. These lawyers are able to provide excessive knowledge and advice to construction companies with regard to specific contracts that are used on a daily basis to regulate the relationship between these companies and their various clients.

'Construction law' is universally understood to cover the whole of the specialised field of law that affects the construction industry and the legal framework through which it operates. ${ }^{4}$ Author John Uff states in his book on Construction law as follows: ${ }^{5}$

In legal terms there is no difference between a building and an engineering contract and the term construction contract is adopted to cover both. Construction law is thus an interactive subject in which both lawyers and construction professionals, including managers have an essential part to play.

Why then are so many law students not even aware of the fact that this branch of law exists and even more so, not aware of the opportunities that lie in this greatly increasing and specialised field? Law students undertake a rigorous four or even five year journey into the exploration of various fields of law reaching fields that are as diverse as international business law or even street law, However after obtaining a LLB degree many legal practitioners are left with little idea, if any at all of the principles that underlie construction and engineering law and thus evidently enter the corporate world with no further training in this field except for their knowledge of basic contract law.

\section{Arguments against the implementation of construction and engineering law in the LLB}

Contracts with regard to construction however, differ greatly from those entered into by consumers such as purchase and sale, letting and hiring or even marriage contracts which law students study thoroughly during their years at university. Many factors make a construction or related services contract different from most other types of contracts. These include the length of the project, its complexity, its size, the immense risk involved and the fact the price agreed upon and the amount of work done may change a number of

$4 \quad$ J Uff Construction law (2013) 1265.

Uff ( 4 above) 1. 
times as the project proceeds. ${ }^{6}$ Unfortunately the LLB degree as it is compiled at present focuses solely on general contract law and other aspects of specific contracts such as sale and lease, yet pay little attention whatsoever to the importance of engineering and construction or services contracts, including building contracts that form a fundamental part of society as we know it.

Some may argue that contract law with regards to construction and engineering may not take place as frequently as, for example, purchase and sale contracts concluded by everyday consumers. However, this is not at all true. Government entities, being one of the construction industries largest consumers, implements new projects on a monthly if not weekly basis that involve creating new infrastructure or improving already existing infrastructure with the aim of creating more job opportunities. ${ }^{7}$ Put aside the government's investment in construction projects and one is left with an immense number of projects that must be completed by large companies in South Africa. For example, Sasol petroleum or even every day entrepreneurs that wish to build malls with their goals fixed on profit in South Africa's rapidly expanding economy. The expenses of any one of these projects may revolve around the millions of Rands, it is thus of utmost importance that these firms hire trained and specialised lawyers that are able to assist them in their construction law matters.

The continued success rate for the completion of these projects is not only subject to the efficient work of engineers, quantity surveyors or project directors but also of legal practitioners. The Preamble of the Construction Industry Development Board $\mathrm{Act}^{8}$ reads in part as follows:

The construction industry impacts directly on communities and the public at large and its improved efficiency and effectiveness will enhance quality, productivity, health, safety, environmental outcomes and value for money to (the) South African society.

The Act in its preamble clearly points out that the 'improved efficiency' of the construction industry will be highly beneficial to the country and this undoubtedly calls for legal practitioners with the necessary knowledge in construction law to assist in the promotion of its effectiveness.

\section{$4 \quad$ From a professional viewpoint}

Even on a weekly basis most people require the services of another, for example for plumbing, electrical services and repairs, cell phone

\footnotetext{
J Adriaanse Construction contract law (2010) 1.

A Venter \& C Landsberg Government and politics in South Africa (2011) 86-87. 38 of 2000 .
} 
and internet network services, and also repairs to and servicing of vehicles. Is it not then, by obvious observation, where $X$ hires $Y$ to perform any one of the previous mentioned services, the conclusion of an important type of contract? With the exception of purchase and sale agreements, construction and services agreements are the most prolific agreements concluded. Although it falls under the Consumer Protection $\mathrm{Act}^{9}$ where it involves a 'consumer', this is not the case for juristic persons. An important question is whether familiarity with and understanding of general contract law and general principles of contract is sufficient for the specific problems that may arise in construction and service contracts. The answer is twofold. It is 'yes', in the sense that all contracts, whether letting and hiring or building contracts are founded and based on the same 'basic principles of contract' that regulate all contracts. But the answer can also very easily be 'no'. For one thing, any legal practitioner who encounters a building or engineering contract for the first time has little or probably no understanding of the nature of the contract. In scope and essence it differs greatly from that of, for example, letting and hiring and he or she will more than likely encounter problems while trying to understand it. Now imagine this on a much larger scale, where the contract in question is a standard form contract undertaken between a construction company and its client, which includes a number of other, smaller sub-contractors. ${ }^{10}$ These contracts are vast in their nature and structure and include clauses that are often bespoke and do not as a general rule appear in any other contracts.

Various forms of alternative dispute resolution and so forth exist in the construction and engineering industry. Legal practitioners with the necessary knowledge in these contracts are essential to the efficient and smooth running of such a large project. Above and beyond the contracts that are regulated by the Consumer Protections Act, the LLB syllabus of most if not all universities in South Africa choose to ignore dedicated training and education with regards to the contracts mentioned above. Training on these essential issues is also not included in the syllabi offered by the Law Schools for candidate attorneys.

\section{The issue at hand}

After taking all of the above mentioned facts into account one must ask the question: 'Where is building and construction law in the present day LLB curriculum?' How can a field that is so rich in opportunity and of fundamental importance to the country's ever-

968 of 2008.

10 CJ Nagel et al Commercial Law (2011) 662-663. 
changing economy be missing in what is regarded as South Africa's universal degree requirement for legal practitioners?

As Law students we are taught not to view the law as an already finished article but rather one that we must help complete. In certain circumstances this calls for criticising what is already thought to be complete. The LLB is aimed at training law students in every core aspect of the law in order that they may enter the corporate world with full knowledge of legal matters facing the country, and the failure to include construction, building and engineering law in the LLB degree leaves them with a serious and problematic gap in their legal education.

If Construction law cannot be included in a general study of specific contracts, this important and vast branch of law should at least be considered as a possible elective module for final year LLB students who wish to increase their knowledge in this field and thus be better equipped for the challenges they might encounter should they wish to follow a legal career in commercial practice or specifically construction and building. 